
in carrot crop fertilization. Horticultura Brasileira 39: 127-132. DOI: http://dx.doi.org/10.1590/s0102-0536-20210201

\title{
Potassium sources and calcium and magnesium doses in carrot crop fertilization
}

\author{
João Rodrigues Neto ${ }^{1 \mathbb{D}}$; Daniel P Pereira ${ }^{1 \mathbb{D}}$; José Luiz R Torres ${ }^{1 \mathbb{D}}$; Fabio J Carvalho ${ }^{1 \mathbb{D}}$; Hamilton César \\ de O Charlo ${ }^{1 \mathbb{D}}$
}

${ }^{1}$ Instituto Federal do Triângulo Mineiro (IFTM), Uberaba-MG, Brasil; jrneto87@gmail.com; danielpena@iftm.edu.br; jlrtorres@iftm.edu. br; fabiojanoni@iftm.edu.br; hamiltoncharlo@iftm.edu.br

\begin{abstract}
Fertilization has an important influence on carrot productivity and on the quality of the produced root, being responsible for most of the production cost of the crop. In this context, we evaluated the use of potassium $(\mathrm{K})$ sources associated with calcium $(\mathrm{Ca})$ and magnesium $(\mathrm{Mg})$ doses in carrot cultivation. In a randomized block design in a triple factorial scheme $(2 \times 2 \times 2)$, we evaluated two doses and sources of potassium [potassium chloride $(\mathrm{KCl}), 120 \mathrm{~kg} \mathrm{ha}^{-1}$ of $\mathrm{K}_{2} \mathrm{O}$; potassium sulfate $\left(\mathrm{K}_{2} \mathrm{SO}_{4}\right) 120 \mathrm{~kg} \mathrm{ha}^{-1}$ of $\mathrm{K}_{2} \mathrm{O}+42,5 \mathrm{~kg} \mathrm{ha}^{-1}$ of $\mathrm{S}$ ]; Two doses of $\mathrm{Mg}$ [magnesium sulfate $\left(\mathrm{MgSO}_{4}\right)$, zero $\mathrm{kg} \mathrm{ha}^{-1}$ of $\mathrm{Mg} ; 25 \mathrm{~kg} \mathrm{ha}^{-1}$ of Mg $+34,2 \mathrm{~kg} \mathrm{ha}^{-1}$ of S]; two doses of the commercial algae product Lithothamnium calcareum as an alternative source of $\mathrm{Ca}$ [zero kg ha-1 of seaweed; $200 \mathrm{~kg} \mathrm{ha}^{-1}$ of seaweed $\left(24 \mathrm{~kg} \mathrm{ha}^{-1}\right.$ of $\mathrm{Ca})$ ], all with six replications. Total productivity, $3 \mathrm{~A}$, commercial and percentage of discard carrot were evaluated. Regardless of the source of $\mathrm{K}$ used, the carrot production was median (above $40 \mathrm{t} \mathrm{ha}^{-1}$ ), with no application of $\mathrm{Ca}$ or $\mathrm{Mg}$. The application of $25 \mathrm{~kg} \mathrm{ha}^{-1}$ of $\mathrm{Mg}$ and zero $\mathrm{Ca}$ altered the $\mathrm{Ca}: \mathrm{Mg}$ ratio in the soil and provided a significant increase in yield when $\mathrm{KCl}$ was used. The association of $L$. calcareum algae with $\mathrm{KCl}$ reduces total yield and increases carrot disposal.
\end{abstract}

Keywords: Daucus carota, Lithothamnium calcareum, potassium chloride, red algae extract, productivity, carrot quality.

\section{RESUMO}

Produção de cenouras submetidas a fontes de potássio e doses de cálcio e magnésio

A adubação tem importante influencia na produtividade da cenoura e na qualidade da raiz produzida, sendo responsável pela maior parte do custo de produção da cultura. Neste contexto, avaliouse a utilização de fontes de potássio $(\mathrm{K})$, associadas a doses de cálcio (Ca) e magnésio $(\mathrm{Mg})$ no cultivo da cenoura. No delineamento de blocos ao acaso, em esquema fatorial triplo $(2 \times 2 \times 2)$, avaliaram-se duas fontes e doses de potássio [cloreto de potássio $(\mathrm{KCl})$, na dose de $120 \mathrm{~kg} \mathrm{ha}^{-1}$ de $\mathrm{K}_{2} \mathrm{O}$; sulfato de potássio $\left(\mathrm{K}_{2} \mathrm{SO}_{4}\right)$ na dose de $120 \mathrm{~kg} \mathrm{ha}^{-1}$ de $\mathrm{K}_{2} \mathrm{O}+42,5 \mathrm{~kg} \mathrm{ha}^{-1}$ de $\mathrm{S}$; duas doses de $\mathrm{Mg}$ [sulfato de magnésio $\left(\mathrm{MgSO}_{4}\right)$, zero kg ha ${ }^{-1}$ de $\left.\mathrm{Mg} ; 25 \mathrm{~kg} \mathrm{ha}^{-1} \mathrm{de} \mathrm{Mg}+34,2 \mathrm{~kg} \mathrm{ha}^{-1} \mathrm{de} \mathrm{S}\right]$; duas doses do produto à base da alga Lithothamnium calcareum como fonte alternativa de $\mathrm{Ca}$ [zero $\mathrm{kg} \mathrm{ha}^{-1}$ de alga; $200 \mathrm{~kg} \mathrm{ha}^{-1}$ de alga $(24 \mathrm{~kg}$ $\left.\mathrm{ha}^{-1} \mathrm{de} \mathrm{Ca}\right)$ ], com seis repetições. Foi avaliada a produtividade total, $3 \mathrm{~A}$, comercial e percentual de cenoura descarte. Independente da fonte de K utilizada, a produção da cenoura foi mediana (acima de 40 t ha-1 ${ }^{-1}$, sem aplicação de Ca ou Mg. A associação de alga L. calcareum com $\mathrm{KCl}$ reduz a produtividade total e aumenta o descarte da cenoura. A utilização da alga L. calcareum como fonte de Ca proporcionou aumento da produção quando associado com a aplicação de $25 \mathrm{~kg}$ ha-1 de $\mathrm{Mg}$ via $\mathrm{MgSO}_{4}$ e quando a fonte de $\mathrm{K}$ foi $\mathrm{K}_{2} \mathrm{SO}_{4}$.

Palavras-chave: Daucus carota, Lithothamnium calcareum, cloreto de potássio, extrato de algas vermelhas, produtividade, qualidade da cenoura.

\section{Received on September 15, 2020; accepted on March 31, 2021}

$\mathrm{C}$ arrot (Daucus carota subsp. sativus) is among the five most cultivated vegetables in Brazil, and the state of Minas Gerais is its largest producer, with 7.1 thousand hectares of planted area, and an average productivity of $39.7 \mathrm{t} \mathrm{ha}^{-1}$, which corresponds to $40 \%$ of the national production; about $80 \%$ of this is located in the Alto Paranaíba and Triângulo Mineiro regions (Beling, 2017).
The carrot production is sustained by high doses of mineral fertilizers. By assessing the crop's nutrient uptake curve, Cecilio Filho \& Peixoto (2013) observed that nitrogen $(\mathrm{N})$, phosphorus $(\mathrm{P})$, potassium $(\mathrm{K})$, magnesium $(\mathrm{Mg})$ and sulfur (S) are the nutrients most accumulated in the roots, whereas calcium $(\mathrm{Ca})$ was more accumulated in the aerial part.

Dezordi et al. (2016), assessing the differences between summer and winter cultivars, observed that there were no differences in the extractions of $\mathrm{N}, \mathrm{P}$, $\mathrm{Ca}, \mathrm{S}$, boron (B), copper $(\mathrm{Cu})$ and zinc $(\mathrm{Zn})$ in both seasons; however, through the nutrient balance, $\mathrm{Mn}, \mathrm{Mg}, \mathrm{K}$ and $\mathrm{Ca}$ were the most limiting nutrients for carrot crops in the Alto Paranaiba region. Gerendás \& Führs (2013) highlight that the balance between $\mathrm{K}, \mathrm{Ca}$ and $\mathrm{Mg}$ is reflected in the crops' quality and 
productivity.

There is a low demand in carrot crops for $\mathrm{K}$ up to 40 days after seeding; afterwards, the demand increases in the plant's aerial part and stabilizes at about 100 days. Meanwhile, in the roots, there is increasing absorption until the end of the cycle (Cecilio Filho \& Peixoto, 2013).

Calcium $(\mathrm{Ca})$ is a constituent element of cell walls and second messenger to environmental stimuli, which makes it essential for the stability of biomembranes and cell walls (Taiz et al., 2017). Of the total accumulated $\mathrm{Ca}$ during the carrot cycle, only $25 \%$ goes to the roots (Cecilio Filho \& Peixoto, 2013); it is usually supplied by liming and phosphate fertilization with single and triple superphosphate, both containing $\mathrm{Ca}$ in its composition.

Some products based on red algae (Lithothamnium calcareum) have been used as an alternative source to the use of limestone as an acid corrector (Melo \& Furtini Neto, 2003; Guiry et al., 2014), also used in agriculture, livestock and human food (Aslam et al., 2010). Nabti et al. (2017) highlight that algaebased products provide $\mathrm{Ca}$, stimulate seed germination, root development and nutrient absorption.

The Mg in plant cells is part of the chlorophyll ring structure and acts on the activation of enzymes involved in respiration, photosynthesis, as well as DNA and RNA synthesis (Taiz et al., 2017), and it is increasingly absorbed by the end of the crop's cycle. However, it is known that there is an antagonistic reaction in $\mathrm{Mg}$ absorption in relation to K (Senbayram et al., 2015). Sulfur (S) is found in certain amino acids (cystine, cysteine and methionine) and is a constituent of several coenzymes and vitamins, such as coenzyme A, S-adenosylmethionine, biotin, vitamin B1 and pantothenic acid, which are essential for metabolism. In addition, it is a constituent of proteins and essential for plant growth and development (Taiz et al., 2017).

Assessing carrot crops' nutritional management is an efficient strategy to improve its productivity and quality for human consumption. Thus, this study's goal was to assess the use of potassium sources associated with calcium and magnesium doses in carrot crops in the Alto Paranaíba-MG region, Brazil.

\section{MATERIAL AND METHODS}

The study was carried out in Guaritas Farm, in the municipality of São Gotardo, state of Minas Gerais, Brazil (19²7'40.0”'S, 4607'53.8'W, $1201 \mathrm{~m}$ altitude), from $01 / 11 / 2018$ to $04 / 16 / 2018$, in a commercial area with center pivot irrigation.

According to the classification by Beck et al. (2018), the region's climate is classified as $\mathrm{Cwb}$, subtropical highland climate, with temperate summers, characterized by a dry season and a well-defined rainy period, which occurs from October to March, with an average temperature of $18^{\circ} \mathrm{C}$ and $850 \mathrm{~mm}$ of average rainfall (Luz et al., 2009).

The region's soil is classified as Dystrophic Red-Yellow Oxisol, with considerably clayey texture (Santos et al., 2018), with the arable layer (0-20 cm) presenting: $\mathrm{pH}\left(\mathrm{H}_{2} \mathrm{O}\right)=6.2 ; \mathrm{P}_{\mathrm{rem}}=$ $12.8 \mathrm{mg} \mathrm{dm}^{-3} ; \mathrm{P}_{\text {resine }}=35.8 \mathrm{mg} \mathrm{dm}^{-3} ; \mathrm{K}=$ $147.2 \mathrm{mg} \mathrm{dm}^{-3} ; \mathrm{Ca}=4.2 \mathrm{cmol}_{\mathrm{c}} \mathrm{dm}^{-3}$; $\mathrm{Mg}=1.4 \mathrm{cmol}_{\mathrm{c}} \mathrm{dm}^{-3} ; \mathrm{S}=18.6 \mathrm{mg} \mathrm{dm}^{-3}$; $\mathrm{H}+\mathrm{Al}=3.1 \mathrm{cmol}_{\mathrm{c}} \mathrm{dm}^{-3} ; \mathrm{CTC}=9.09 \mathrm{cmol}_{\mathrm{c}}$ $\mathrm{dm}^{-3} ; \mathrm{SB}=5.99 \mathrm{cmol}_{\mathrm{c}} \mathrm{dm}^{-3}$, organic matter $(\mathrm{OM})=3.1 \mathrm{dag} \mathrm{kg}^{-1}$ and $\mathrm{V} \%=66$. Regarding the micronutrients, $\mathrm{B}=0.8$ $\mathrm{mg} \mathrm{dm}{ }^{-3} ; \mathrm{Cu}=2.7 \mathrm{mg} \mathrm{dm}^{-3} ; \mathrm{Fe}=32.4$ $\mathrm{mg} \mathrm{dm}{ }^{-3} ; \mathrm{Mn}=9.5 \mathrm{mg} \mathrm{dm}^{-3}$ and $\mathrm{Zn}=$ $18.6 \mathrm{mg} \mathrm{dm}^{-3}$ were found. According to the results of the soil analysis and the classification proposed by Alvarez et al. (1999), the P and K contents in the soil are classified as "very good" and those of $\mathrm{Ca}$ and $\mathrm{Mg}$ as "good".

The study was carried out in a randomized complete block design, with a triple factorial scheme $(2 \times 2 \times 2)$, using the following treatments: Two doses of potassium in the form: 1 Potassium chloride (KCl), $120 \mathrm{~kg} \mathrm{ha}^{-1}$ of $\mathrm{K}_{2} \mathrm{O} ; 2$ - Potassium sulfate $\left(\mathrm{K}_{2} \mathrm{SO}_{4}\right)$ $120 \mathrm{~kg} \mathrm{ha}^{-1}$ of $\mathrm{K}_{2} \mathrm{O}+42,5 \mathrm{~kg} \mathrm{ha}^{-1}$ of $\mathrm{S}$; Two doses of magnesium using magnesium sulfate $\left(\mathrm{MgSO}_{4}\right)$ : 1 - zero $\mathrm{Mg} ; 2$ - $25 \mathrm{~kg} \mathrm{ha}^{-1}$ of $\mathrm{Mg}+34,2 \mathrm{~kg} \mathrm{ha}^{-1}$ of S; two doses of the commercial algae product Lithothamnium calcareum as an alternative source of Calcium $(\mathrm{Ca})$ :
1 - Zero seaweed; 2 - $200 \mathrm{~kg} \mathrm{ha}^{-1}$ of seaweed $\left(24 \mathrm{~kg} \mathrm{ha}^{-1}\right.$ of $\left.\mathrm{Ca}\right)$, all with six replications.

The $\mathrm{K}_{2} \mathrm{SO}_{4}$ contains $48 \% \mathrm{~K}_{2} \mathrm{O}$ and $17 \% \mathrm{~S}$, while $\mathrm{MgSO}_{4}$ contains $9.5 \% \mathrm{Mg}$ and $13 \% \mathrm{~S}$ in its composition.

Once the base fertilization was completed, we provided $40 \mathrm{~kg} \mathrm{ha}^{-1}$ of $\mathrm{N}$ and $600 \mathrm{~kg} \mathrm{ha}^{-1}$ of $\mathrm{P}_{2} \mathrm{O}_{5}$, supplied via MAP $\left(10 \% \mathrm{~N}\right.$ and $\left.48 \% \mathrm{P}_{2} \mathrm{O}_{5}\right)$ and triple superphosphate $(41 \%$ to $46 \% \mathrm{P}$ and $10 \%$ to $12 \% \mathrm{Ca}$ ) in all treatments, as recommended by Raij et al. (1997). There was no fertilization with manure or organic compounds in the experimental area.

The Lithothamnium calcareum mineral extract contains $12 \%$ calcium, $1 \%$ magnesium and measurable levels of 77 other minerals (Table 1); it is sold as a dietary supplement under the name Aquamin ${ }^{\circledR}$ (GRAS 000028) and is used in a variety of products for human consumption in Europe, Asia, Australia and North America.

The area was prepared in a conventional manner, with subsoiler, harrowing and rotary hoe, leaving the soil free of clods. The base fertilizer was applied manually (by hauling) at the moment of planting and according to each treatment; then a rotary tiller bed former was used to create the beds; in sequence planting was made with a mechanical seeder. There was no need to correct the soil acidity in the study area.

Planting was done in beds measuring $0.3 \mathrm{~m}$ high $\times 1.80 \mathrm{~m}$ wide: four double lines were distributed, with spacing of $0.25 \mathrm{~m}$ between them, and of $0.15 \mathrm{~m}$ between single lines. The experimental units (beds) were $1.8 \mathrm{~m}$ wide $\times 4.0 \mathrm{~m}$ long, and the plot's useful area were the two central double lines, dismissing 1 $m$ of each end of the plot, which were considered borders.

Sowing was carried out mechanically on $11 / 01 / 2018$, using the Juliana hybrid carrot cultivar from the Seminis company, characterized by being a summer-adapted cultivar. 800.000 seeds/ha were sown; thinning was performed 30 days after sowing to standardize the stand on 700.000 plants/ ha.

The remaining crop treatments, 
covering fertilization, spraying, thinning and others were conducted according to routine and specific technical guidelines for carrot cultivation.

Irrigation was performed via central pivot, with a blade to replace the calculated evapotranspiration. The reference evapotranspiration (ETo) was estimated by applying the PenmanMonteith equation, on a daily basis (Allen et al., 2006).

At the end of the cycle, on $04 / 16 / 2018$, the useful area's whole plants were harvested, and the root was used to determine productive variables: total and commercial productivity, $3 \mathrm{~A}$ productivity (category chosen due to higher market remuneration), and percentage of disposed carrots. The carrot $3 \mathrm{~A}$ is characterized by its length varying between 22 and $26 \mathrm{~mm}$.

Roots were used to determine the total yield of each plot (Totprod), weighing all harvested roots. For all productive variables, the roots were weighed with the aid of an electronic scale and the data were converted to $\mathrm{t} \mathrm{ha}^{-1}$.

Then, the roots were classified with the support of carrot washers from the region of São Gotardo-MG, Brazil; these professionals are trained to perform carrot classification in the following categories: disposal, 1A, 2A, 3A and G. Once the carrots were classified, each category was weighed. The sum of the weights of categories $1 \mathrm{~A}, 2 \mathrm{~A}$, $3 \mathrm{~A}$ and $\mathrm{G}$ were defined as commercial productivity (Comprod). We calculated the percentage of disposed carrots (\%Disp) in relation to Totprod to perform a disposal evaluation.

Each category's average price in the region's market was monitored for a two-month period. Drawing from these data, a weight correction was made according to the market price of all categories for the $3 \mathrm{~A}$ category (Prod3A). This analysis is interesting when working with crops that have a qualitative yield factor, and can be considered economic yield.

The normality of data (Lilliefors) and homogeneity of error variances were assessed by the Cochran \& Barttlet test for all data. The results were submitted to a variance analysis with the application of the F test; the mean values were compared to each other by the Tukey test at $5 \%$ probability, with the aid of the R Core Team software.

\section{RESULTS AND DISCUSSION}

Through the variance analysis ( $\mathrm{F}$ test), we observed that there were single and triple interactions between sources of potassium $(\mathrm{K})$, calcium $(\mathrm{Ca})$ and magnesium $(\mathrm{Mg})$. Concerning the analyzed variables, significant interactions occurred only for sources of potassium $(\mathrm{K})$ in the disposal percentage (\% Disp); for sources of calcium (Ca) in category 3A (Prod3A) and between sources of $\mathrm{K} \times \mathrm{Mg} \times \mathrm{Ca}$ in commercial productivity (Comprod).

These interactions evidence the fact that $\mathrm{Mg}$ alone does not interfere with carrot production; $\mathrm{K}$ and $\mathrm{Ca}$ are the elements that most affect it. $\mathrm{K}$ is one of the most required nutrients by plants, and its rates are two to threefold in comparison to $\mathrm{Ca}$ (Taiz et al., 2017). Therefore, $K$ is an essential element for plant growth, yet in the plant system, it is an extremely dynamic ion with high soil mobility. The risk of $\mathrm{K}$ leaching is low in soils of medium and clayey texture, but high in sandy soils, influencing the critical levels in soil and plant. $\mathrm{Ca}$, in turn, is an element that acts synergistically in the accumulation of nutrients such as $\mathrm{P}, \mathrm{K}, \mathrm{Mg}, \mathrm{S}$, and sodium $(\mathrm{Na})$, and this evidences the importance for balanced nutrition in carrot crops (Singh et al., 2012).

Some studies demonstrate that $\mathrm{K}$ has the function of transporting carbohydrates from the source (leaves) to the sinks, which, in the case of carrots, are the tuberous roots. Thus, the proper supply of $\mathrm{K}$ to crops allows the formation of roots of higher commercial

Table 1. Mineral composition of seaweed Lithothamnium calcareum. Uberaba, IFTM, 2018.

\begin{tabular}{lccccc}
\hline Element & $\mu \mathrm{g} \mathbf{g}^{-1}$ & Element & $\mu \mathrm{g} \mathbf{g}^{-1}$ & Element & $\mu \mathrm{g} \mathbf{g}^{-1}$ \\
\hline Aluminum & 291 & Hafnium & $<0.03$ & Rubidium & 1.95 \\
Antimony & 6.74 & Holmium & $<0.05$ & Ruthenium & 0.088 \\
Arsenic & $<0.2$ & Indium & 0.052 & Samarium & 0.529 \\
Barium & 64.2 & Iodine & 32.8 & Scandium & 0.041 \\
Beryllium & 0.306 & Iridium & $<0.05$ & Selenium & 0.672 \\
Bismuth & 0.081 & Iron & 915 & Silicon & 504 \\
Boron & 39.5 & Lanthanum & 0.372 & Silver & 0.250 \\
Bromine & 10.1 & Lead & 0.158 & Sodium & 4,150 \\
Cadmium & 0.070 & Lithium & 2.77 & Strontium & 1,810 \\
Calcium & 351,500 & Lutetium & 0.065 & Sulfur & 5,700 \\
Carbon & 122,000 & Magnesium & 25,800 & Tantalum & 0.060 \\
Cerium & 2.17 & Manganese & 57.5 & Tellurium & 0.048 \\
Cesium & 0.096 & Mercury & 0.008 & Terbium & 0.030 \\
Chloride & 910 & Molybdenum & 0.052 & Thallium & 0.088 \\
Chromium & 0.820 & Neodymium & 0.034 & Thorium & $<0.02$ \\
Cobalt & 0.082 & Nickel & 1.48 & Thulium & 0.061 \\
Copper & 4.89 & Niobium & 0.142 & Tin & 0.197 \\
Dysprosium & 0.078 & Osmium & $<0.05$ & Titanium & 27.8 \\
Erbium & 4.27 & Palladium & $<0.01$ & Tungsten & 0.188 \\
Europium & 0.051 & Phosphorus & 310 & Vanadium & 37.5 \\
Fluoride & 7.28 & Platinum & $<0.01$ & Ytterbium & 0.096 \\
Gadolinium & 0.109 & Potassium & 5,176 & Yttrium & 1.22 \\
Gallium & 2.48 & Praseodymium & 0.228 & Zinc & 15.8 \\
Germanium & 0.207 & Rhenium & $<0.05$ & Zirconium & 0.339 \\
Gold & $<0.01$ & Rhodium & $<0.01$ & & \\
\hline Soure: As & $0.2010)$ & & & &
\end{tabular}

Source: Aslam et al. (2010). 
quality (Filgueira, 2008). Evaluating the extraction of macronutrients by the carrot as a function of $\mathrm{K}$ doses in cover, Corrêa \& Cardoso (2017) observed that they follow a decreasing order of extraction by the aerial part, root and total $\mathrm{K}>\mathrm{Ca}>\mathrm{N}>\mathrm{Mg}>\mathrm{S}>\mathrm{P}$; $\mathrm{K}>\mathrm{N}>\mathrm{C}$ a $>\mathrm{P}>\mathrm{S}>\mathrm{M} \mathrm{g}$ a n $\mathrm{K}>\mathrm{N}>\mathrm{Ca}>\mathrm{P}>\mathrm{Mg}>\mathrm{S}$, respectively and that there were no differences between the doses evaluated for $\mathrm{Ca}, \mathrm{Mg}$ and $\mathrm{S}$.

By analyzing the total carrot yield using the same dose of $\mathrm{K}\left(120 \mathrm{~kg} \mathrm{ha}^{-1}\right)$, regardless of the source $\left(\mathrm{KCl}\right.$ or $\left.\mathrm{K}_{2} \mathrm{SO}_{4}\right)$, and without the application of $\mathrm{Mg}$ (zero dose), the application of $200 \mathrm{~kg} \mathrm{ha}^{-1}$ of calcium, using the commercial algae product Lithothamnium calcareum as an alternative source, did not cause any changes in crop yield (Table 2).

However, applying $25 \mathrm{~kg} \mathrm{ha}^{-1}$ of $\mathrm{Mg}$ using $\mathrm{KCl}$ as $\mathrm{K}$ source, the yield increases by $31 \%$ at zero $\mathrm{Ca}$ dose (without algae application), and by $20 \%$ when compared to using $\mathrm{K}_{2} \mathrm{SO}_{4}$ as the $\mathrm{K}$ source. Using $\mathrm{K}_{2} \mathrm{SO}_{4}$ as the $\mathrm{K}$ source, adding $200 \mathrm{~kg} \mathrm{ha}^{-1}$ of algae-based $\mathrm{Ca}$, the yield increases by $29.4 \%$ compared to $\mathrm{KCl}$ as a $\mathrm{K}$ source. Nonetheless, the yield is statistically equal to the treatment without the use of seaweed, which demonstrates that the potassium source being used is likely to be the one directly influencing the production, which can be justified by the high solubility and absorption of $\mathrm{K}$ when using any of the sources $(\mathrm{KCl}$ or $\mathrm{K}_{2} \mathrm{SO}_{4}$ ) and that the addition of 200 $\mathrm{kg} \mathrm{ha}^{-1}$ of $\mathrm{Ca}$ via algae, caused better plant development and higher carrot productivity.

In this study, higher carrot yields have been observed with the application of $\mathrm{K}$ in coverage, and the crop has not always responded to the addition of calcium, since this nutrient's main effect on carrot production is indirect, through the soil's $\mathrm{Ca} / \mathrm{Mg}$ ratio. In general, for most crops to present good yields, the $\mathrm{Ca} / \mathrm{Mg}$ need should be equivalent to $\mathrm{Ca}: \mathrm{Mg}$ rate between 3 and 4 in the soil (Raij et al., 1997). In this study, the initial chemical analysis of the soil already had a ratio equal to 3 , which must have increased with the application of $\mathrm{Ca}$ doses in the treatments, which justifies the results presented for $\mathrm{Ca}$ and $\mathrm{Mg}$.

Evaluating cover fertilization with $\mathrm{N}, \mathrm{K}$ and $\mathrm{Ca}$ in commercial carrot production, Luz et al. (2009) observed that the combined application of sources increased the productivity of commercial roots, especially roots between 18 and $22 \mathrm{~cm}$ (classification 2A), results similar to those found in this study for $\mathrm{K}(\mathrm{KCl}$ source).

Assessing nutrient accumulation and exportation in "Forto" carrots, Cecilio Filho \& Peixoto (2013) observed that $\mathrm{N}, \mathrm{P}, \mathrm{K}, \mathrm{Mg}$ and $\mathrm{S}$ were preferentially accumulated in the root, while Ca mainly in the leaves; the decreasing order of accumulation was $\mathrm{K}>\mathrm{N}>\mathrm{Ca}>\mathrm{P}>\mathrm{S}>\mathrm{Mg}$, attesting the importance of $\mathrm{K}$ and $\mathrm{Ca}$ in production due to their higher extractions. $\mathrm{Mg}$ is the nutrient least extracted by the plant, and the small amounts in the soil are sufficient to nourish the plant, which may justify the carrot's lack of response to the application of $\mathrm{Mg}$ in the present study.

Concerning the amount and percentage of disposed carrots

Table 2. Commercial production ( $\mathrm{t} \mathrm{ha}^{-1}$ ) (Comprod) of carrots grown with potassium (K), magnesium (Mg) and calcium (Ca) doses in São Gotardo. Uberaba, IFTM, 2018.

\begin{tabular}{lccccc}
\hline \multirow{2}{*}{ Source } & \multicolumn{3}{c}{ Mg1 } & & \multicolumn{2}{c}{ Mg2 } \\
\cline { 2 - 3 } \cline { 5 - 6 } & Ca1 & Ca2 & & Ca1 & Ca2 \\
\hline $\mathrm{KCl}$ & $30.2 \mathrm{aA}$ & $29.7 \mathrm{aA}$ & & $36.5 \mathrm{aA}$ & $25.2 \mathrm{bB}$ \\
$\mathrm{K}_{2} \mathrm{SO}_{4}$ & $33.9 \mathrm{aA}$ & $31.3 \mathrm{aA}$ & & $29.2 \mathrm{bA}$ & $35.7 \mathrm{aA}$ \\
\hline $\mathrm{CV}(\%)$ & \multicolumn{3}{c}{8.99} \\
\hline
\end{tabular}

*Means followed by the same lowercase letter in the column and uppercase on the line do not differ from each other by the Tukey test $(\mathrm{p}<0.05) . \mathrm{KCl}$ and $\mathrm{K}_{2} \mathrm{SO}_{4}=$ potassium chloride and potassium sulfate at $120 \mathrm{~kg} \mathrm{ha}^{-1}$ of $\mathrm{K}_{2} \mathrm{O} ; \mathrm{Mg} 1$ and $\mathrm{Mg} 2=$ magnesium sulfate $\left(\mathrm{MgSO}_{4}\right)$ at zero dose and $25 \mathrm{~kg} \mathrm{ha}^{-1}$ of $\mathrm{Mg}$; $\mathrm{Ca} 1$ and $\mathrm{Ca} 2=$ zero dose and $200 \mathrm{~kg} \mathrm{ha}^{-1}$ of seaweed (24 $\mathrm{kg} \mathrm{ha}^{-1}$ of $\mathrm{Ca}$ ), with Lithothamnium calcareum algae product, respectively.

production, we observed that the use of $\mathrm{K}_{2} \mathrm{SO}_{4}$ as a $\mathrm{K}$ source caused losses of $1.7 \mathrm{t} \mathrm{ha}^{-1}$, which was $24 \%$ lower when compared to the use of $\mathrm{KCl}$. There were no statistical differences between $\mathrm{Ca}$ and $\mathrm{Mg}$ sources (Table 3). These differences may be influenced by the sulfur $(\mathrm{S})$ available in fertilization with $\mathrm{K}_{2} \mathrm{SO}_{4}$ (42.5 $\mathrm{kg} \mathrm{ha}^{-1}$ of S), which provided better conditions for plant development.

Soluble or exchangeable $\mathrm{K}$ may occasionally be included among the major constituents of soil salinity when applied as chloride $(\mathrm{KCl})$ or sulfate $\left(\mathrm{K}_{2} \mathrm{SO}_{4}\right)$, and less often as nitrate. Nonetheless, excess salts in the soil in any of these forms may hinder plant growth and yield due to the osmotic effects and toxicity of specific ions present in high concentrations in the soil solution. Even though soils of medium and clayey texture are less subject to salinization effects caused by fertilizers when compared to sandy soils, this condition should be evaluated when choosing the type of fertilizer to be used, as well as application amounts and frequency (Taiz et al., 2017).

Regarding the commercial carrot production, we observed that there

Table 3. Disposal of total carrot production not classified for sale, grown with potassium $(\mathrm{K})$, magnesium $(\mathrm{Mg})$ and calcium $(\mathrm{Ca})$ doses in São Gotardo. Uberaba, IFTM, 2018.

\begin{tabular}{lccc}
\hline \multirow{2}{*}{ Source } & \multicolumn{3}{c}{ Disposal (t ha $\left.\mathbf{~ h a}^{-1}\right)$} \\
\cline { 2 - 4 } & $\mathbf{K}$ & $\mathbf{M g}$ & $\mathbf{C a}$ \\
\hline 1 & $9.5 \mathrm{a}$ & $8.8 \mathrm{a}$ & $9.6 \mathrm{a}$ \\
2 & $7,8 \mathrm{~b}$ & $8.5 \mathrm{a}$ & $7.7 \mathrm{a}$ \\
\hline $\mathrm{CV}(\%)$ & \multicolumn{4}{c}{26.51} \\
\hline \multicolumn{4}{c}{ Disposal (\%) } \\
\hline 1 & $24.5 \mathrm{a}$ & $20.8 \mathrm{a}$ & $23.7 \mathrm{a}$ \\
2 & $18,5 \mathrm{~b}$ & $22.2 \mathrm{a}$ & $19.3 \mathrm{a}$ \\
\hline CV (\%) & \multicolumn{3}{c}{11.39} \\
\hline
\end{tabular}

*Means followed by the same lowercase letter in the column do not differ from each other by the Tukey test $(\mathrm{p}<0.05)$. K: $1=$ potassium chloride $(\mathrm{KCl})$ and $2=$ potassium sulfate $\left(\mathrm{K}_{2} \mathrm{SO}_{4}\right)$ at a dose of $120 \mathrm{~kg} \mathrm{ha}^{-1}$ of $\mathrm{K}_{2} \mathrm{O} ; \mathrm{Mg}$ : 1 and 2 = magnesium sulfate $\left(\mathrm{MgSO}_{4}\right)$ at zero dose and $25 \mathrm{~kg} \mathrm{ha}^{-1}$ of $\mathrm{Mg}$; Ca 1 and $2=$ dose zero and $200 \mathrm{~kg} \mathrm{ha}^{-1}$ of seaweed $\left(24 \mathrm{~kg} \mathrm{ha}^{-1}\right.$ of Ca), with commercial product based on Lithothamnium calcareum algae, respectively. 
were no differences between the $\mathrm{K}$ sources and $\mathrm{Ca}$ and $\mathrm{Mg}$ doses used, and the values varied between 39.7 and $42.8 \mathrm{tha}^{-1}$, depending on the $\mathrm{K}$ source used $\left(\mathrm{KCl}_{\text {or }} \mathrm{K}_{2} \mathrm{SO}_{4}\right)$. We also observed that the production of Prod3A carrots is equivalent to practically $9 \%$ of total carrot production (Totprod), and the production of this category increased when there was calcium application (Table 4).

These results indicate that the practice of liming for $\mathrm{pH}$ correction is sufficient to meet the demands of the crop in $\mathrm{Ca}$ and $\mathrm{Mg}$, causing the levels of these nutrients to rise in the soil in sufficient quantities to supply the plant, which can be proven through the previous chemical analysis of the soil, where the levels of $\mathrm{Ca}$ and $\mathrm{Mg}$ were classified as very good and good, respectively, justifying the lack of effect of the application of $\mathrm{Ca}$ and $\mathrm{Mg}$.

Evaluating commercial carrot yield with different potassium doses, Silva et al. (2016) conducted data adjustment with quadratic regression, in which the maximum point was $61.5 \mathrm{~kg} \mathrm{ha}^{-1}$ of $\mathrm{K}_{2} \mathrm{O}$, while fresh matter production reached a

Table 4. Total carrot production (Totprod, $\left.\mathrm{t} \mathrm{ha}^{-1}\right)$ and those classified as 3A (Prod3A) grown with doses of potassium $(\mathrm{K})$, magnesium $(\mathrm{Mg})$ and calcium $(\mathrm{Ca})$ in São Gotardo. Uberaba, IFTM, 2018.

\begin{tabular}{lccc}
\hline \multirow{2}{*}{ Source } & \multicolumn{3}{c}{ Totprod $\left(\mathbf{t ~ h a}^{-1}\right)$} \\
\cline { 2 - 4 } & $\mathbf{K}$ & $\mathbf{M g}$ & $\mathbf{C a}$ \\
\hline 1 & $42.1 \mathrm{a}$ & $41.2 \mathrm{a}$ & $42.8 \mathrm{a}$ \\
2 & $40.5 \mathrm{a}$ & $41.4 \mathrm{a}$ & $39.7 \mathrm{a}$ \\
\hline $\mathrm{CV}(\%)$ & \multicolumn{3}{c}{6.85} \\
\hline \multicolumn{4}{c}{ Prod3A } \\
\hline $\mathrm{KCl}$ & $4.2 \mathrm{a}$ & $4.2 \mathrm{a}$ & $4.5 \mathrm{a}$ \\
$\mathrm{K}_{2} \mathrm{SO}_{4}$ & $4.4 \mathrm{a}$ & $4.4 \mathrm{a}$ & $4.1 \mathrm{~b}$ \\
\hline $\mathrm{CV}(\%)$ & \multicolumn{3}{c}{25.8} \\
\hline
\end{tabular}

$\mathrm{K}: 1=$ potassium chloride $(\mathrm{KCl})$ and $2=$ potassium sulfate $\left(\mathrm{K}_{2} \mathrm{SO}_{4}\right)$ at a dose of $120 \mathrm{~kg}$ ha $^{-1}$ of $\mathrm{K}_{2} \mathrm{O} ; \mathrm{Mg}$ : 1 and $2=$ magnesium sulfate $\left(\mathrm{MgSO}_{4}\right)$ at zero dose and $25 \mathrm{~kg} \mathrm{ha}^{-1}$ of $\mathrm{Mg}$; $\mathrm{Ca} 1$ and $2=$ dose zero and $200 \mathrm{~kg} \mathrm{ha}^{-1}$ of seaweed ( $24 \mathrm{~kg} \mathrm{ha}^{-1}$ of Ca), with commercial product based on Lithothamnium calcareum algae, respectively. *Means followed by the same lowercase letter in the column do not differ from each other by the Tukey test $(\mathrm{p}<0.05)$. maximum of $87.7 \mathrm{~kg} \mathrm{ha}^{-1}$ of $\mathrm{K}_{2} \mathrm{O}$, which evidences that $\mathrm{K}$ influenced in the root's commercial classification.

According to Luz et al. (2009), in an experiment also conducted in the region of São Gotardo-MG, the total number of carrot roots was not significantly affected by topdressing treatments, totaling maximum root yield $\left(27.5 \mathrm{tha}^{-1}\right)$; when using the 20-00-20 formulation, the values obtained were lower than those obtained by this study with the application of the $229.1 \mathrm{~kg} \mathrm{ha}^{-1}$.

In their study, Zanfirov et al. (2012) observed that the maximum yield obtained in carrot cultivation (103.8 $\mathrm{t} \mathrm{ha}^{-1}$ ) occurred using $41.6 \mathrm{~kg}$ $\mathrm{ha}^{-1}$ of $\mathrm{K}_{2} \mathrm{O}$ and, when compared to the control without potassium application $\left(90.7 \mathrm{tha}^{-1}\right)$; there was a $14 \%$ increase in the production, values higher than those found in this study.

$\mathrm{K}$ is the main nutrient related to the quality of production and/or product, as it takes part in the activation of several enzymes during photoassimilate biosynthesis and carbohydrate transport (Taiz et al., 2017), that's why it is more accumulated in all parts of the plant (Corrêa \& Cardoso, 2017). The importance of $\mathrm{K}$ in carrot production was evidenced in this study, regardless of the $\mathrm{K}$ source used $\left(\mathrm{KCl}\right.$ or $\left.\mathrm{K}_{2} \mathrm{SO}_{4}\right)$. There was high yield with the $120 \mathrm{~kg}$ $\mathrm{ha}^{-1}$ dose when no $\mathrm{Mg}$ was applied, or without Lithothamnium calcareum application as source of $\mathrm{Ca}$.

The soil Ca: $\mathrm{Mg}$ ratio before planting was 3, which is considered ideal in other studies (Filgueira, 2008; Luz et al., 2009); when altered by the application of $25 \mathrm{~kg} \mathrm{ha}^{-1}$ of $\mathrm{Mg}$ and zero Ca there was a significant increase in production when the $\mathrm{K}$ source was $\mathrm{KCl}$. However, applying $200 \mathrm{~kg} \mathrm{ha}^{-1}$ of Lithothamnium calcareum algae as $\mathrm{Ca}$ source, the production dropped substantially, which confirms the need to maintain this relationship.

The combination of Lithothamnium calcareum algae with potassium chloride $(\mathrm{KCl})$ in carrots base fertilizer reduced the total yield and increased the disposed carrot classification. The use of $L$. calcareum algae as a Ca source only provided a significant increase in production if applied along with $25 \mathrm{~kg}$ $\mathrm{ha}^{-1}$ of $\mathrm{Mg}$ using magnesium sulfate $\left(\mathrm{MgSO}_{4}\right)$, when the $\mathrm{K}$ source was potassium sulfate $\left(\mathrm{K}_{2} \mathrm{SO}_{4}\right)$.

The association of $L$. calcareum algae with $\mathrm{KCl}$ reduces total productivity and increases carrot disposal, however, as a Ca source, it only provided a significant increase in production when associated with the application of $25 \mathrm{~kg} \mathrm{ha}^{-1}$ of $\mathrm{Mg}$ via $\mathrm{MgSO}_{4}$ and when the source of $\mathrm{K}$ was $\mathrm{K}_{2} \mathrm{SO}_{4}$.

\section{ACKNOWLEDGMENTS}

To the Federal Institute of Triângulo Mineiro, Campus Uberaba, for the infrastructure provided; to the Brazilian National Council for Scientific and Technological Development (CNPq), to the Coordination of Superior Level Staff Improvement (CAPES) by granting scholarships to the students.

\section{REFERENCES}

ALlEN, RG; PEREIRA, LS; RAES, D; SMITH, M. 2006, Evapotranspiración del cultivo: Guias para la determinación de los requerimientos de água de los cultivos. Roma: FAO. 298p. (Estudio FAO Riego y Drenaje, 56).

ALVAREZ VVH; NOVAIS RF; BARROS NF (eds). 1999. Interpretação dos resultados das análises de solos. In: RIBEIRO AC; GUIMARÃES PTG; ALVAREZ VVH. Recomendações para o uso de corretivos e fertilizantes em Minas Gerais. 5a. Aproximação. Viçosa: CFSEMG. p.25-32.

ASLAM, MN; KREIDER, JM; PARUCHURI, T; BHANGAVTHULA, N; SILVA, M; ZERNICKE, RF.; GOLDSTEIN, SA; VARANI, J. 2010. A mineral-rich extract from the red marine alga Lithothamnion calcareum preserves bone struture and function in female mice on a Western-style diet. Calcified Tissue International 86: 313-324.

BECK, HE; ZIMMERMANN, NE; MCVICAR, TR; VERGOPOLAN, N; BERG, A; WOOD, EF. 2018. Present and future Köppen-Geiger climate classification maps at 1-km resolution. Scientific Data 1: 1-12.

BELING, RR. 2017. Anuário Brasileiro de Hortaliças. Edit. Gazeta. 60p.

CECILIO FILHO, AB; PEIXOTO, FC. 2013. Acúmulo e exportação de nutrientes em cenoura "Forto". Caatinga 26: 64-70.

CORRÊA, CV; CARDOSO, AII. 2017. Extração de macronutrientes em cenoura em função das doses de potássio em cobertura. Cultivando o Saber 10: 278-285.

DEZORDI, LR; AQUINO, LA; AQUINO, RFBA; CLEMENTE, JM; ASSUNÇÃO, NS. 2016. 
Diagnostic methods to assess the nutritional status of the carrot crop. Revista Brasileira de Ciência do Solo 40: 1-16.

FILGUEIRA, FAR. 2008. Novo manual de olericultura: Agrotecnologia moderna na produção e comercialização de hortaliças. Viçosa: UFV, $3^{\mathrm{a}}$ edição, 421p.

GERENDÁS, J; FÜHRS, H. 2013. The significance of magnesium for crop quality. Plant and Soil 368: 101-128.

GUIRY, MA; GUIRY, GM; MORRISON, L; RINDI, F; MIRANDA, V; MATHIESON, AC; PARKER, BC; LANGANGEN, A; JOHN, DM; BÁRBARA, I; CARTER, CF; KUIPERS, P; GARBARY, DJ. 2014. AlgaeBase: an on-line resource for Algae. Cryptogamie, Algologie 35: 105-115.

LUZ, JMQ; ZORZAL FILHO, A; RODRIGUES, WL; QUEIROZ, AA. 2009. Adubação de cobertura com nitrogênio, potássio e cálcio na produção comercial de cenoura. Horticultura Brasileira 26: 543-548.

MELO, PC; FURTINI NETO, AE. 2003. Avaliação do Lithothamnium como corretivo da acidez do solo e fonte de nutrientes para feijoeiro. Ciência e Agrotecnologia 27: 508-519.

NABTI, E; JHA, B; HARTMANN, A. 2017. Impact of seaweeds on agricultural crop production as biofertilizer. International Journal of Environmental Science and Technology 14: 1119-1134.

RAIJ, BV; CANTARELLA, H; QUAGGIO, JA; FULANI, AMC. 1997. Recomendações de adubação e calagem para o Estado de São Paulo. $2^{\mathrm{a}}$ ed. Campinas: IAC. (Boletim Técnico, 100), 285p.

SANTOS, HG; JACOMINE, PKT; ANJOS, LHC; OLIVEIRA, VA; LUMBRERAS, JF; COELHO, MR; ALMEIDA, JA; CUNHA, TJF; OLIVEIRA, JB. 2018. Sistema brasileiro de classificação de solos. 3.ed., Brasília: Embrapa Informação Tecnológica, 355p.

SENBAYRAM, M; GRANSEE, A; WAHLE, V; THIEL, H. 2015. Role of magnesium fertilizers in agriculture: Plant-soil continuum. Crop and Pasture Science 66: 1219-1229.

S ILVA, A C B ; S C HU QUEL, L C S ; SILVA,CO;ASCOAL, GB. 2016. Qualidade nutricional e físico-química em cenoura (Daucus carota L.) in natura e minimamente processada. Demetrav 11: 355-367.

SINGH, DP; BELOY, J; INERNEY, JK; DAY, L. 2012. Impact of boron, calcium and genetic factors on vitamin $\mathrm{C}$, carotenoids, phenolic acids, anthocyanins and antioxidant capacity of carrots (Daucus carota). Food Chemistry 132: 1161-1170.

TAIZ, L; ZEIGER, E; MOLLER, IM; MURPHY, A. 2017. Fisiologia e desenvolvimento vegetal. $6^{\mathrm{a}}$ ed. Porto Alegre: Artmed, $888 \mathrm{p}$.

ZANFIROV, CA; CORREA, CV; CARPANETTI, MG; CORREA, FF; CARDOSO, AII. 2012. 